Article

\title{
Impact of Temperature on the Performance and Character of the Methanogenic Community of a Fixed-Bed Anaerobic Reactor at Psychrophilic Temperature
}

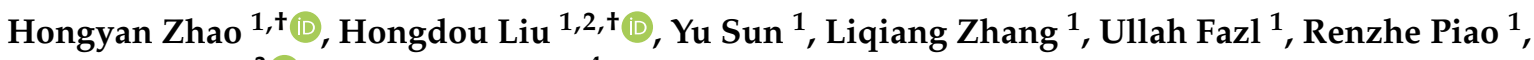 \\ Weidong Wang ${ }^{3(\mathbb{D}}$ and Zongjun Cui ${ }^{4, *}$ \\ 1 College of Agronomy, Yanbian University, Yanji 133002, China; zhy@ybu.edu.cn (H.Z.); \\ Liuhongdoudou@126.com (H.L.); sunyu1688@outlook.com (Y.S.); 2020010597@ybu.edu.cn (L.Z.); \\ ullahfazl@163.com (U.F.); piaorz@ybu.edu.cn (R.P.) \\ 2 College of Land and Environment, Shenyang Agricultural University, Shenyang 110866, China \\ 3 Heilongiiang Provincial Key Laboratory of Environmental Microbiology and Recycling of Argo-Waste in Cold \\ Region, College of Life Science and Technology, Heilongjiang August First Land Reclamation University, \\ Daqing 163000, China; wwdcyy@126.com \\ 4 College of Agronomy and Biotechnology, Center of Biomass Engineering, China Agricultural University, \\ Beijing 100193, China \\ * Correspondence: acuizj@cau.edu.cn; Tel./Fax: +86-10-62731857 \\ + Liu and Zhao contribute equality to this work.
}

\section{check for}

updates

Citation: Zhao, H.; Liu, H.; Sun, Y.; Zhang, L.; Fazl, U.; Piao, R.; Wang, W.; Cui, Z. Impact of Temperature on the Performance and Character of the Methanogenic Community of a Fixed-Bed Anaerobic Reactor at Psychrophilic Temperature. Water 2021, 13, 3051. https://doi.org/ 10.3390/w13213051

Academic Editor: Constantinos V. Chrysikopoulos

Received: 20 August 2021

Accepted: 29 October 2021

Published: 1 November 2021

Publisher's Note: MDPI stays neutral with regard to jurisdictional claims in published maps and institutional affiliations.

Copyright: (c) 2021 by the authors. Licensee MDPI, Basel, Switzerland. This article is an open access article distributed under the terms and conditions of the Creative Commons Attribution (CC BY) license (https:/ / creativecommons.org/licenses/by/ $4.0 /)$.

\begin{abstract}
To determine the effects of a gradual temperature decrease on reactor performance and the microbial community, four fixed-bed reactors that were packed with a biofilm carrier were operated for 217 days. The temperature of the reactors was decreased from $30{ }^{\circ} \mathrm{C}$ to $3^{\circ} \mathrm{C}$. The reactors initially soured at $3^{\circ} \mathrm{C}$ and recovered when they were returned to $4{ }^{\circ} \mathrm{C}$, as indicated by the stabilization of biogas production, methane production, VFA concentration, $\mathrm{pH}$, and the COD removal rate. Our results also revealed that methanomicrobiales were the dominant methanogen, the concentration of the 16S rRNA gene in the carbon-fiber carrier sludge exceeded the same gene concentration in the deposited sludge, and that the carbon-fiber carrier played an important role in methanomicrobiale colonization at low temperatures. We suggest that $4{ }^{\circ} \mathrm{C}$ is the low-temperature threshold for optimal reactor performance.
\end{abstract}

Keywords: fixed-bed reactor; molasses wastewater; low-temperature anaerobic digestion; methanomicrobiale

\section{Introduction}

Anaerobic digestion, which simultaneously produces biogas for use as fuel and reduces pollution, is an effective method for reducing biodegradable organic matter in wastewater [1]. Compared with traditional wastewater treatment methods, anaerobic digestion has the advantages of higher organic load capacity, reduced reactor volume, significantly less sludge generation, and relatively low costs of operation and maintenance $[2,3]$.

Temperature has a strong effect on the efficiency of anaerobic digestion. Although previous studies have demonstrated successful wastewater treatment via anaerobic digestion, the typical operation temperatures for full-scale anaerobic digesters are thermophilic $\left(45-65^{\circ} \mathrm{C}\right)$ or mesophilic $\left(20-45^{\circ} \mathrm{C}\right)[4,5]$. The requirement of these relatively warm temperatures is significant because much of the industrial effluent from wastewater treatment plants is discharged at $\leq 10^{\circ} \mathrm{C}$ in the northern, colder regions of China, where the freezing period lasts for 3-6 months, and the average temperature of wastewater is $5-9{ }^{\circ} \mathrm{C}$ [6]. Domestic wastewater in Europe and the USA has an annual mean temperature of approximately $18^{\circ} \mathrm{C}$ on average, and the common occurrence of domestic wastewater temperatures below $20^{\circ} \mathrm{C}$, which may occur in winter months, has greatly increased the interest in psychrophilic anaerobic treatment of cold wastewater [7-9]. Previous research confirmed that 
it is feasible to treat wastewater at low temperatures, and the anaerobic digester energy input and associated operating costs can be significantly reduced by treating wastewater at the discharge temperature [10-14]. Low-temperature bioreactors have reduced heating requirements and thus provide cost savings in comparison with more costly mesophilic and thermophilic bioreactors that are used for the treatment of sub-ambient waste streams. However, a sufficient amount of bioenergy must be harvested in order to allow for sustainable waste treatment and thus make long-term low-temperature operation an economically feasible process $[11,15]$. Therefore, low-temperature treatment of wastewater is feasible and saves energy.

Several studies have indicated that operating anaerobic digesters at low temperatures is a viable option for the treatment of several wastewater types (e.g., trichloroethylene wastewater and synthetic wastewater) and this practice is currently used in a variety of bioreactor types (e.g., upflow anaerobic sludge blanked (UASB), expanded granularsludge bed (EGSB), fixed-bed, anaerobic sequencing batch reactor (ASBR), and anaerobic membrane bioreactor (AMBR)), in which the reactor operating time ranges from 78 days to 1234 days and the dominant microbes are methanomicrobiales and methanosaetaceae [3,11,16-18]. However, our teams have confirmed that anaerobic fixed-bed reactors with a carbon-fiber biofilm show very good performance in the treatment of molasses wastewater at low temperatures, with a high OLR (organic loading rate) and high resistance to shock. The amount of methane that is produced by such reactors is greater than that produced by other reactors. The highest stable operating efficiency of a fixedbed reactor was $4.33 \mathrm{~kg} \mathrm{COD} / \mathrm{m}^{3} \cdot \mathrm{d}$ at $4{ }^{\circ} \mathrm{C}$, and the methane content was $77 \%$ at $5{ }^{\circ} \mathrm{C}$. Biofilms that are formed by sludge adhering to a supporting material are more active than suspended sludge, and the attachment of sludge on the carrier lengthens the average residence time, thereby providing the appropriate conditions for slow-growing microbes (especially methanomicrobiales), which can improve the shock resistance and stability of the reactor when it is subjected to adverse environmental conditions. Under shock conditions, methanomicrobiale-related populations probably play an important role in anaerobic granular-sludge systems, in which the main pathway for methane production is hydrogenotrophic methanogenesis.

Molasses is commonly used as a feedstock for fermentation [18-22]. It is necessary to treat molasses-processed wastewater since it contains abundant cations, anions and organic compounds. Molasses is commonly used to produce amino acids, ethanol, and enzymes. The COD concentration of molasses is high $(50,000-100,000 \mathrm{mg}$ COD/L), and it has a low pH value (4-5) [14]. Therefore, compared with other wastewaters (e.g., trichloroethylene wastewater and synthetic wastewater), molasses wastewater is more difficult to treat and causes operational issues for reactors performing anaerobic biological treatment. In previous research, we confirmed that fixed-bed anaerobic reactors had impact resistance and high methane content when used to treat molasses wastewater at low temperatures $[14,18,22]$. However, no study has evaluated fix-bed reactor operation at decreasing temperatures in order to assess the microbial community for molasses wastewater treatment at low temperatures.

Thus, the goal of this study was to investigate the operation parameters and dynamics of the microbial community in a fixed-bed reactor that was operated at a gradually decreasing temperature. The temperature effects were evaluated based on the relative COD removal rate, methane content, $\mathrm{pH}$, VFA concentration and biogas production. During the first 217 days of operation, the microbial composition within the reactor was also determined.

\section{Materials and Methods}

\subsection{Bioreactor}

A synthetic glass (10 mm thick) fixed-bed reactor, with a $10 \mathrm{~L}$ effective volume, was packed with active carbon fiber (Japan Carbon Company, Tokyo, Japan) and operated under anaerobic conditions using molasses wastewater (MWW) as the feed. The reactor 
had the following dimensions: $24 \mathrm{~cm}$ outer diameter and $30 \mathrm{~cm}$ height. The biofilm carriers were comprised of six cylindrical carbon-fiber textiles $(5.5 \mathrm{~cm}$ inner diameter, $27 \mathrm{~cm}$ height, $2 \mathrm{~mm}$ thick, Japan Carbon Company, Tokyo, Japan) that were packaged using stainless steel wire and inserted into the reactor. A peristaltic pump was used to pump MWW into the reactor, and a valve near the top of the reactor was used for biogas collection (Figure 1). Water displacement was used to determine the sample volume. Reactor effluent $(30-50 \mathrm{~mL})$ was sampled regularly. Biogas samples and bioreactor effluent were collected to measure the volatile fatty acid (VFA), chemical oxygen demand (COD), $\mathrm{pH}$, and methane $\left(\mathrm{CH}_{4}\right)$ content. A water quality monitor (Lovi-bond 99731COD, Dortmund, Germany) was used to measure the COD. High-performance liquid chromatography (LC-MS2020, Japan) was used to determine the VFA content. A separation column $(300 \times 7.8 \mathrm{~mm}$; Aminex model HPX-87H; Bio-Rad Laboratories, Hercules, CA, USA) with a mobile phase of $0.05 \mathrm{M} \mathrm{H}_{2} \mathrm{SO}_{4}$ $(\mathrm{pH}, 2.2)$ and a flow rate of $1 \mathrm{~mL} / \mathrm{min}$ was used. A Horiba Compact $\mathrm{pH}$ meter (Model B-212, HORIBA, Fukuoka, Japan) was used to measure pH. A biogas analyzer (Model ADG, Landtec, CA, USA) was used to measure $\mathrm{CH}_{4}$ content. Samples were taken every day for analysis, and VFAs were measured at varying temperatures $\left(30^{\circ} \mathrm{C}, 10^{\circ} \mathrm{C}, 8^{\circ} \mathrm{C}, 6^{\circ} \mathrm{C}, 5^{\circ} \mathrm{C}\right.$, $4{ }^{\circ} \mathrm{C}$, and $3{ }^{\circ} \mathrm{C}$ ). To regulate the operating temperature, the bioreactor was positioned in a biochemical incubator (Model MIR 254, Sanyo, Osaka, Japan).

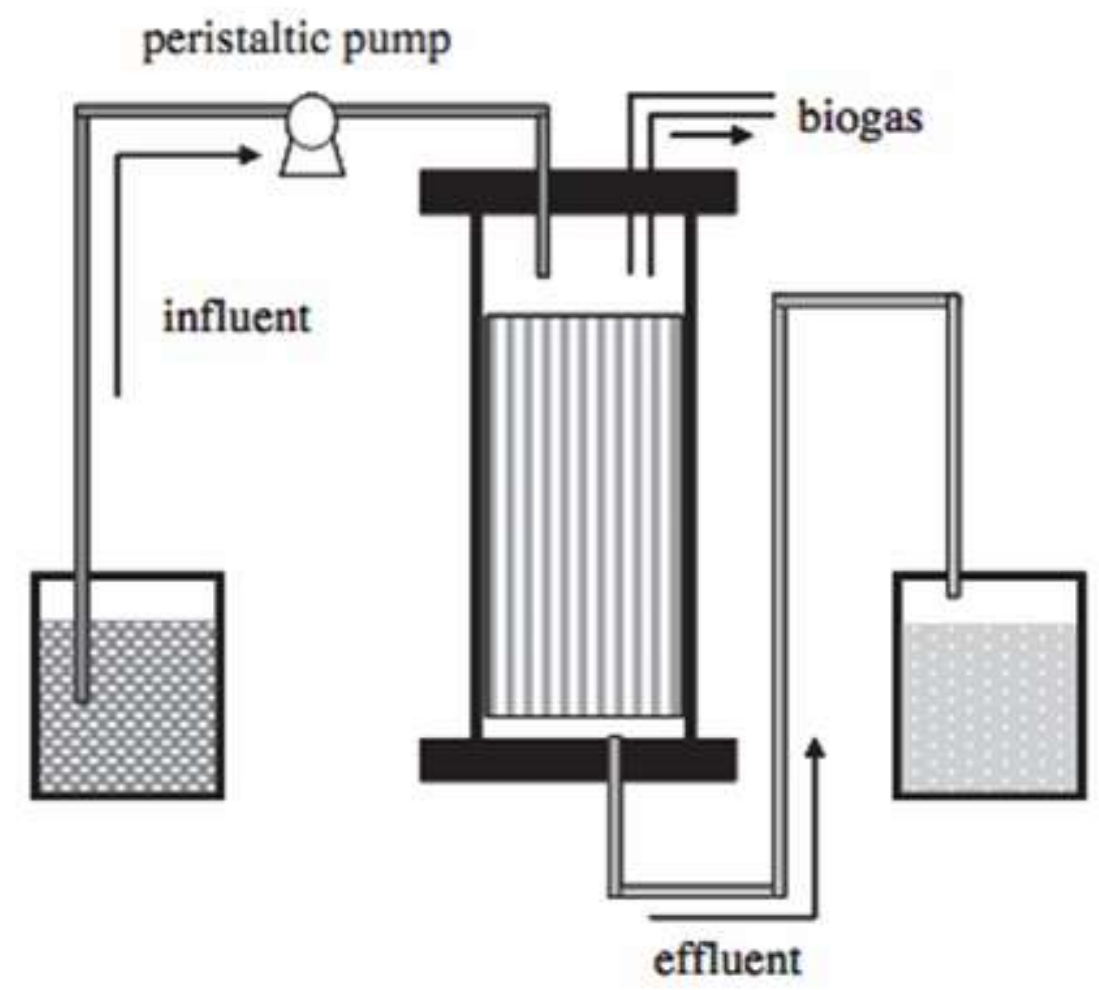

Figure 1. Schematic of a fixed-bed anaerobic reactor.

\subsection{Feeding Solution and Seed Sludge}

The artificial wastewater consisted of tap water $(90 \mathrm{~L}$, initial COD of 100,000 mg/L), molasses (10 L, sag: $70 \%$; brix: $45 \%$ ), and commercial cat food ( $800 \mathrm{~g}$, composed mainly of protein, fat and crude fiber, Whiskas, Beijing, China), which was diluted with water in order to achieve the target COD in each experiment. The COD:N:P ratio, which was kept at 300-500:5:1, ensured that the microorganisms in the reactor received sufficient nutrients ( $\mathrm{N}$ and $\mathrm{P}$ ). Granular sludge (4 L) was acquired from a full-scale Coca-Cola production wastewater treatment plant and grown under mesophilic conditions for inoculation. The inoculated sludge contained $33.63 \%$ total solid (TS) and $6.16 \%$ volatile solid contents. After inoculation, the TS content of the sludge that was adhering to the carbon fiber was $12.90 \%$, whereas that of the deposited fraction was $10.01 \%$. After inoculation, the VS content of the 
sludge that was adhering to the carbon fiber was $12.17 \%$, whereas that of the deposited fraction was $8.85 \%$ [23]. At $4{ }^{\circ} \mathrm{C}$, the TS content of the sludge that was adhering to the carbon fiber was $11.38 \%$, whereas that of the deposited fraction was $9.08 \%$. At $4{ }^{\circ} \mathrm{C}$, the VS content of the sludge that was adhering to the carbon fiber was $8.50 \%$, whereas that of the deposited fraction was $7.82 \%$ [23].

\subsection{Experimental Protocol}

During the operation time, the reactor's hydraulic retention time (HRT) was constant ( 3 days), and MWW was the main source of carbon for microbial growth. The experiments were divided into three operation phases (Table 1), which were characterized by changes in temperature and COD. In order to verify the operating temperature threshold and the methanomicrobiale colonization of the carbon-fiber carrier fixed-bed reactor operating at low temperatures, we confirmed that the fixed-bed reactor could be operated at the low temperatures of $5{ }^{\circ} \mathrm{C}$ and $4{ }^{\circ} \mathrm{C}[14,18]$, but whether this is the temperature threshold for low-temperature operation has not been confirmed. Therefore, we selected 4 reactors with exactly the same specifications and types for this study. The fixed-bed anaerobic reactor temperature was reduced from $35^{\circ} \mathrm{C}$ to $3{ }^{\circ} \mathrm{C} 200$ days after the reactors had reached a steady state at the designated OLR, as determined by stable $\mathrm{pH}$ and methane yield. When the operating temperature of the reactor was between $30-20^{\circ} \mathrm{C}$, the temperature and OLR were decreased stepwise by $5{ }^{\circ} \mathrm{C}$ and $0.67 \mathrm{~kg} \mathrm{COD} / \mathrm{m}^{3} \cdot \mathrm{d}$. When the reactor operating temperature was between $18-6{ }^{\circ} \mathrm{C}$, the temperature was decreased stepwise by $2{ }^{\circ} \mathrm{C}$, while the OLR was kept constant $\left(1.67 \mathrm{~kg} \mathrm{COD} / \mathrm{m}^{3} \cdot \mathrm{d}\right)(2 \mathrm{HRTs} / 6$ days). To reach the threshold of a fixed-bed anaerobic reactor operating at low temperatures, the systems were operated for 6 HRTs (18 days) at constant temperatures of $10^{\circ} \mathrm{C}, 8^{\circ} \mathrm{C}$, and $6{ }^{\circ} \mathrm{C}$ for R1, R2, and R3, respectively. For R4, the OLR $\left(0.67 \mathrm{~kg} C O D / \mathrm{m}^{3} \cdot \mathrm{d}\right)$ was kept constant while the temperature was decreased stepwise in increments of $1{ }^{\circ} \mathrm{C}$ after reaching $6{ }^{\circ} \mathrm{C}$. The system temperature was maintained at $5{ }^{\circ} \mathrm{C}$ and $4{ }^{\circ} \mathrm{C}$ for 4 HRTs (12 days) and 10 HRTs (30 days), respectively. The reactor was acidified at $3{ }^{\circ} \mathrm{C}$ for 17 days. To confirm that the reactor operated stably at $4{ }^{\circ} \mathrm{C}$, the temperature was returned to $4{ }^{\circ} \mathrm{C}$ for 6 HRTs (18 days), after which the methane, $\mathrm{pH}, \mathrm{COD}$ removal rate, VFA, and biogas production returned to pre-acidification levels. Automatic titration $(5 \mathrm{~N} \mathrm{NaOH})$ was used to keep the $\mathrm{pH}$ of the MWW at $7.0 \pm 0.2$.

Table 1. Fixed-bed reactor operating parameters.

\begin{tabular}{ccccccc}
\hline Operation Stage & T $\left({ }^{\circ} \mathbf{C}\right)$ & HRT & $\begin{array}{c}\text { Operation Time } \\
\text { (Day) }\end{array}$ & $\begin{array}{c}\text { Molasses Add } \\
(\mathbf{g} / \mathbf{d})\end{array}$ & $\begin{array}{c}\text { Influent COD } \\
(\mathbf{m g} / \mathbf{L})\end{array}$ & $\begin{array}{c}\text { OLR } \\
\left(\mathbf{k g ~ C O D} / \mathbf{m}^{3} \cdot \mathbf{d}\right)\end{array}$ \\
\hline Start-up & $35 \pm 0.2$ & 13 & $1-78$ & $102.56 \pm 0.1$ & $20,000 \pm 1$ & $6.67 \pm 0.1$ \\
\hline & $30 \pm 0.2$ & 2 & $79-85$ & $102.56 \pm 0.1$ & $20,000 \pm 1$ & $6.67 \pm 0.1$ \\
& $25 \pm 0.2$ & 2 & $86-91$ & $76.92 \pm 0.1$ & $15,000 \pm 1$ & $5.00 \pm 0.1$ \\
& $20 \pm 0.2$ & 2 & $92-97$ & $51.28 \pm 0.1$ & $10,000 \pm 1$ & $3.33 \pm 0.1$ \\
& $18 \pm 0.2$ & 2 & $98-103$ & $25.64 \pm 0.1$ & $5000 \pm 1$ & $1.67 \pm 0.1$ \\
& $16 \pm 0.2$ & 2 & $104-109$ & $25.64 \pm 0.1$ & $5000 \pm 1$ & $1.67 \pm 0.1$ \\
Decrease state & $14 \pm 0.2$ & 2 & $110-115$ & $25.64 \pm 0.1$ & $5000 \pm 1$ & $1.67 \pm 0.1$ \\
& $12 \pm 0.2$ & 2 & $116-121$ & $25.64 \pm 0.1$ & $5000 \pm 1$ & $1.67 \pm 0.1$ \\
& $10 \pm 0.2$ & 2 & $122-128$ & $25.64 \pm 0.1$ & $5000 \pm 1$ & $1.67 \pm 0.1$ \\
& $8 \pm 0.2$ & 2 & $129-134$ & $25.64 \pm 0.1$ & $5000 \pm 1$ & $1.67 \pm 0.1$ \\
& $6 \pm 0.2$ & 2 & $135-140$ & $25.64 \pm 0.1$ & $5000 \pm 1$ & $1.67 \pm 0.1$ \\
& $5 \pm 0.2$ & 4 & $141-152$ & $10.26 \pm 0.1$ & $2000 \pm 1$ & $0.67 \pm 0.1$ \\
\hline Source state & $3 \pm 0.2$ & 6 & $153-182$ & $10.26 \pm 0.1$ & $2000 \pm 1$ & $0.67 \pm 0.1$ \\
\hline Recovery state & $4 \pm 0.2$ & 6 & $183-200$ & $10.26 \pm 0.1$ & $2000 \pm 1$ & $0.67 \pm 0.1$ \\
\hline
\end{tabular}




\subsection{DNA Extraction and Conventional PCR}

Samples of fixed-bed reactor granular sludge were collected at varying temperatures $\left(30^{\circ} \mathrm{C}, 10^{\circ} \mathrm{C}, 8{ }^{\circ} \mathrm{C}, 6^{\circ} \mathrm{C}, 5^{\circ} \mathrm{C}, 4^{\circ} \mathrm{C}\right.$, and $\left.3^{\circ} \mathrm{C}\right)$. Adherent sludge on the carbon-fiber biofilm (approximately $5 \mathrm{~mm}$; designated as adhering sludge) was collected directly from the reactor from three separate sheets of active carbon fiber $(15 \mathrm{~mm} \times 30 \mathrm{~mm} \times 2 \mathrm{~mm})$. The deposited sludge was collected from the valves located at the bottom of the reactor. After 40 days of operation, the adhering and deposited sludge showed different characteristics. Operating the reactor at low temperatures caused a deposition of slurry-like sludge on the reactor bottom (deposited sludge). Adhering sludge was comprised of granules ranging from 2 to $5 \mathrm{~mm}$ in size. When the operating temperature was $4{ }^{\circ} \mathrm{C}$, the adhering sludge was dense, spherical, and 4 to $5 \mathrm{~mm}$ thick with a high settlement rate. However, the adhering sludge was drawn off when the operating temperature was $3^{\circ} \mathrm{C}$.

Sediment samples ( $0.3 \mathrm{~g}$ net weight), which were obtained by centrifuging granularsludge samples (10 $\mathrm{min}, 8000 \mathrm{rpm}$ ) and removing the supernatant, were used for DNA extraction. The VSS concentration was used to determine the biomass amount necessary for DNA extraction. Genomic DNA for PCR was obtained using an automated nucleic acid extractor (Bioteke Biotech Co., Ltd., Beijing, China) and stored at $-20^{\circ} \mathrm{C}$. PCR amplification was achieved with a GeneAmp PCR System (Model 9700, Applied Biosystems, Waltham, MA, USA) using the following protocol: initial denaturing, 10 min at $95^{\circ} \mathrm{C} ; 29$ cycles, $1 \mathrm{~min}$ at $9{ }^{\circ} \mathrm{C}, 1 \mathrm{~min}$ at $50^{\circ} \mathrm{C}$, and $1.5 \mathrm{~min}$ at $72{ }^{\circ} \mathrm{C}$; a final extension step of $5 \mathrm{~min}$ at $72{ }^{\circ} \mathrm{C}$. PCR products were evaluated for further analysis using electrophoresis on $2 \%$ agarose gels.

\subsection{Microbial Community Analysis with PCR-DGGE}

Amplification of the $\mathrm{V} 3$ region of the $16 \mathrm{~S}$ rRNA gene was achieved with the following primer set using a GC-clamp: 348F, 5'-GGIGCAICAGGCGCGAAA-3'; 806R-GC, 5' CGCCCGCCGCGCCCCGCGCCCGGCCCGCCGCCCCC-GCCCCGGACTACCIGGGTITCTAA$3^{\prime}$ [24]. DCodeTM system (Bio-Rad Laboratories, Hercules, CA, USA) was used for denaturing gradient gel electrophoresis (DGGE) analysis, as previously described. PCR-DGGE determination was conducted according to the method of Salvador et al. [25]. The BLAST Program and the GenBank data library were used to determine sequence similarities. Gels were digitally imaged for quantification of bands (Quantity One, Bio-Rad, Hercules, CA, USA). The relative intensity of each band was calculated as a ratio of band intensity and the total intensity of all bands in the relevant lane.

\section{6. $16 \mathrm{~S}$ rRNA Gene Clone Library and Phylogenetic Tree Analysis}

The following PCR primers for archaeal communities were used: A109f (5'-ACKGC TCAGTAACACGT-3') and A912r (5'-GTGCTCCCCCGCCAATTCCTTTA-3') [26]. After purification (TIANgel Midi Purification Kit, Tiangen Biotech, Beijing, China), PCR products were inserted into the pGEM-T Easy Vector (Promega, Madison, WI, USA) according to the manufacturer's directions. A total of 192 colonies were obtained; 50 colonies were randomly chosen for sequence analysis. Each clone resulted in a single band with a distinctive melting position. Sequence similarity was determined based on the BLAST database from Genbank (http:/ / www.ncbi.nlm.nih.gov/BLAST/ accessed on 27 September 2020). A phylogenetic tree was created using CLUSTAL $X$ and MEGA 4.0 software by employing the neighborjoining method $[27,28]$.

\subsection{Quantitative PCR of Methanogens}

Quantitative real-time PCR (Q-PCR) was performed using the primers and probes previously described [29] as follows: Methanobacteriales(MBT), amplicon size: $343 \mathrm{bp}$, MBT857F, MBT929F, MBT1196R; Methanococcales(MCC), amplicon size: 337 bp, MCC495F, MCC686F, MCC813R; Methanomicrobiales(MMB), amplicon size: 506 bp, MMB282F, MMB749F, MMB832R; Methanosarcinaceae(MSC), amplicon size: 408 bp, MSC380F, MSC492F, MSC828R; and Methanosaetaceae (MST), amplicon size: 164 bp, MST702F, MST753F, MST862R. TaqMan probes labeled with a 5' FAM fluorophore reporter and a 3' BHQ-1 
(black hole quencher) were used. The Q-PCR reaction mix (20 $\mu \mathrm{L})$ was as follows: $2 \times$ TaqMan Universal PCR Master mix (Applied Biosystems, USA), $5 \mu \mathrm{L}$ of PCR-grade water, $1 \mu \mathrm{L}$ of each primer (10 $\mu \mathrm{M}$ final), $2 \mu \mathrm{L}$ of the probe $(1 \mu \mathrm{M}$ final), $10 \mu \mathrm{L}$ of $2 \times$ reaction solution, and $1 \mu \mathrm{L}$ of template DNA. A two-step amplification was achieved using the following protocol: denaturation for $10 \mathrm{~min}$ at $94{ }^{\circ} \mathrm{C}$, followed by 40 cycles, $10 \mathrm{sec}$ at $94{ }^{\circ} \mathrm{C}$, then a combined annealing and extension period of $30 \mathrm{sec}$ at $60^{\circ} \mathrm{C}\left(63^{\circ} \mathrm{C}\right.$ for the MMB primer set). An ABI 7500 system (Model 7500, Applied Biosystems, USA) was used.

Q-PCR standards were generated from genomic DNA of five archaea species: methanobacteriales (Methanobrevibacter arboriphilus NBRC101200), methanococcales (Methanococcus voltae NBRC100457), methanomicrobiales (Methanospirillum hungatei NBRC100397), methanosarcinaceae (Methanosarcina acetivorans NBRC100939), and methanosaetaceae (Methanosaeta thermophila NCBR101360), provided by the NITE Biological Research Center (NBRC, Chiba, Japan). Target rRNA gene sequences for each strain were amplified with conventional PCR, using the previously described primers. The resultant PCR products were cloned into the pGEM-TEasy Vector. Standard Q-PCR curves for each plasmid were generated using 10 -fold serial dilutions $\left(10^{2}\right.$ to $10^{9}$ copies per $\left.\mu \mathrm{L}\right)$. Within a linear range, corresponding standard curves were used to estimate the 16S rRNA gene copy concentration of each target. Granule biomass-based concentrations (copies/g granule VSS) were calculated from the volume-based concentrations (copies/ $\mu \mathrm{L}$ ) based on VSS concentration of the corresponding granular-sludge sample. Duplicate samples from the bioreactor were analyzed for each primer/probe set.

\section{Results and Discussion}

\subsection{Bioreactor Performance}

The biogas production rate can be used to monitor the operating conditions of a reactor and explore the characteristics of anaerobic biofilm formation and microbial physiological activity during reactor operation $[21,30]$. The temperature of the four reactors gradually decreased over the first 217 days of operation. The start-up phase was described by Zhao for 78 days at $35{ }^{\circ} \mathrm{C}$ [30]. The biogas production rate gradually decreased as the temperature was reduced, which indicated that the microbial community of the fixed-bed reactor was shocked or stressed by the decrease in temperature, and the community later adapted, after which the level of biogas production stabilized. When the temperature reached $18{ }^{\circ} \mathrm{C}$ from days $98-103$, biogas production significantly increased from $3.71 \mathrm{~L} / \mathrm{kg} \mathrm{COD} / \mathrm{m}^{3} \cdot \mathrm{d}$ to $4.82 \mathrm{~L} / \mathrm{kg} \mathrm{COD} / \mathrm{m}^{3} \cdot \mathrm{d}$, whereas the COD removal rate significantly decreased from $51.03 \%$ to $37.42 \%$, and the $\mathrm{pH}$ and methane production were stable at 7.0 and $38.99 \mathrm{NL} / \mathrm{Kg} \cdot \mathrm{VS}$, respectively. The COD removal rate was affected, but the $\mathrm{pH}$ and methane content remained stable. This effect was likely observed because the reactor was temperature-shocked at $20{ }^{\circ} \mathrm{C}$, but the COD removal stabilized at about $75 \%$ when the operating temperature of the reactor was gradually decreased to $16^{\circ} \mathrm{C}$. This is a common problem with anaerobic wastewater treatment at low temperatures, and a similar phenomenon has been confirmed in other studies $[9,11]$.

A previous study reported that temperature was a critical factor for effective COD removal, and the COD removal efficiency was about $50 \%$ at $20{ }^{\circ} \mathrm{C}$ [31], which agreed with the results of the experiments assessing COD removal efficiency. Several previous studies have reported that anaerobic fermentation is extremely sensitive to $\mathrm{pH}$, and the optimum $\mathrm{pH}$ for anaerobic fermentation is 6.0-8.0. In addition, the stable operation of fixed-bed anaerobic reactors at low temperatures requires the methane content of the biogas to exceed $50 \%[14,18,21]$. The methanogenic activity of the dominant methanogens in the fixed-bed reactor was likely maintained at a high level during treatment of high-strength molasses diluted in water. It has been reported that the reactor start-up at $18^{\circ} \mathrm{C}$ and the addition of microbial consortia that are acclimatized to low temperatures have achieved good results, and acceptable biogas production has been reported at temperatures ranging from $15-20{ }^{\circ} \mathrm{C}$ using psychrophilic digesters underneath swine facilities, and the rate of gas production was highest at $18^{\circ} \mathrm{C}[18,32,33]$. Many anaerobic methanogenic archaea 
with optimal growth temperatures of $15-25^{\circ} \mathrm{C}$ have been isolated [34], and domestic wastewater in Europe and the USA has an annual mean temperature of approximately $18^{\circ} \mathrm{C}$ on average [7]. From the perspective of heat consumption, most industrial effluents are discharged under $18{ }^{\circ} \mathrm{C}$, and treating wastewaters at their discharge temperatures could increase the economic feasibility of anaerobic digestion, thereby resulting in a net increase in energy yield $[8,35]$.

When the temperature reached $10^{\circ} \mathrm{C}$, biogas production was significantly decreased, whereas the $\mathrm{COD}$ removal rate, $\mathrm{pH}$, and methane content remained stable. At $8{ }^{\circ} \mathrm{C}$, biogas production was significantly increased from $1.97 \mathrm{~L} / \mathrm{kg} \mathrm{COD} / \mathrm{m}^{3} \cdot \mathrm{d}$ to $3.2 \mathrm{~L} / \mathrm{kg} \mathrm{COD} / \mathrm{m}^{3} \cdot \mathrm{d}$, methane production was increased from $16.78 \mathrm{NL} / \mathrm{Kg} \cdot \mathrm{VS}$ to $23.42 \mathrm{NL} / \mathrm{Kg} \cdot \mathrm{VS}$, and $\mathrm{pH}$ and the COD removal rate remained stable. A previous report assessed the operating conditions of a reactor at the low temperature of $8{ }^{\circ} \mathrm{C}[9,11]$. When an EGSB-AF reactor was temperature-shocked at $8.5-9{ }^{\circ} \mathrm{C}$, the $\mathrm{COD}$ removal was $34 \%$, but stabilization of the operational temperature of the reactor at $10{ }^{\circ} \mathrm{C}$ led to a gradual recovery of the system [11]. We considered that $8^{\circ} \mathrm{C}$ was an important temperature threshold for biogas production by fixed-bed anaerobic reactors.

In the $\mathrm{R} 4$ reactor, the COD removal rate (55\%), $\mathrm{pH}(7.0)$, biogas production $(1.0 \mathrm{~L} / \mathrm{kg}$ $\left.\mathrm{COD} / \mathrm{m}^{3} \cdot \mathrm{d}\right)$, and methane production $(16.27 \mathrm{NL} / \mathrm{Kg} \cdot \mathrm{VS})$ remained stable at $4{ }^{\circ} \mathrm{C}$. The $\mathrm{pH}$ was particularly stable, and $\mathrm{pH}$ is known to be a very sensitive index in anaerobic digestion [21]. Most previous investigations used various reactors in series for treatment of real wastewater and simulated wastewater at $4{ }^{\circ} \mathrm{C}[7,9,11,14,36]$.

When the temperature was gradually reduced to $3{ }^{\circ} \mathrm{C}$, the $\mathrm{COD}$ removal rate, $\mathrm{pH}$, biogas production, and methane production reduced rapidly $\left(15 \%, 5.5,0.04 \mathrm{~L} / \mathrm{kg} \mathrm{COD} / \mathrm{m}^{3} \cdot \mathrm{d}\right.$, $42.56 \mathrm{NL} / \mathrm{Kg}$.VS). In addition, the reactor became soured, and a significant amount of granule sludge on the carbon-fiber carrier began to fall off. Previous studies established that EGSB reactors and anaerobic membrane reactors can operate at $3{ }^{\circ} \mathrm{C}$ for the treatment of simulated wastewater $[7,37]$. At present, there have been no reports of fixed-bed reactors operating at $3{ }^{\circ} \mathrm{C}$. The studies mentioned above mainly assessed synthetic wastewater, while this study used real wastewater, which is an important difference [9]. When the operational temperature of the reactor was stabilized at $4{ }^{\circ} \mathrm{C}$ (day 201-217), the system recovered steadily, and the optimum values of $\mathrm{COD}$ removal rate, $\mathrm{pH}$, biogas production, methane production were $60.78 \%, 7.2,1.47 \mathrm{~L} / \mathrm{kg} \mathrm{COD} / \mathrm{m}^{3} \cdot \mathrm{d}$, and $13.68 \mathrm{NL} / \mathrm{Kg} \cdot \mathrm{VS}$, respectively (Figure 2). These results suggest that $4{ }^{\circ} \mathrm{C}$ is an important temperature threshold for the carbon-fiber carrier in a fixed-bed reactor.

The continued operation of the R4 reactor at low temperatures was monitored, and the variation of the VFA effluent was determined (Figure 3). As the temperature was decreased to $18{ }^{\circ} \mathrm{C}$, propionate acid accumulated, likely because the $5^{\circ} \mathrm{C}$ drop in temperature slowed the conversion of accumulated VFA to $\mathrm{CH}_{4}, \mathrm{CO}_{2}$, and other organics. This change was likely followed by acetogenic bacterial degradation of propionate to form acetate at $20^{\circ} \mathrm{C}$. Subsequently, biogas production was increased at $18^{\circ} \mathrm{C}$. Propionate accumulated again at $12^{\circ} \mathrm{C}$, and biogas production increased again at $8^{\circ} \mathrm{C}$. This phenomenon indicated that the fixed-bed reactor was shocked, and the methanogens on the carbon-fiber carrier that were fermenting complex organic compounds had yet to adapt to this temperature, as observed in other studies [7]. Following a gradual decrease in temperature, VFA accumulated at $3{ }^{\circ} \mathrm{C}$. The acetate concentration and propionate concentration increased from $0.02 \mathrm{~g} / \mathrm{L}$ and $0.016 \mathrm{~g} / \mathrm{L}$, respectively, at $30^{\circ} \mathrm{C}$ to $0.32 \mathrm{~g} / \mathrm{L}$ and $0.64 \mathrm{~g} / \mathrm{L}$, respectively, at $3{ }^{\circ} \mathrm{C}$. The propionate content at $3{ }^{\circ} \mathrm{C}$ was 40 -fold higher than that at $30^{\circ} \mathrm{C}$. Propionate oxidation is very sensitive during psychrophilic anaerobic treatment, and the increase in acetate and propionate concentrations in the bioreactor suggested the inhibition of these populations in the suspended biomass [37]. During the 138-day period, $\mathrm{pH}$ rapidly dropped from 7.6 at $30^{\circ} \mathrm{C}$ to 5.5 at $3{ }^{\circ} \mathrm{C}$; moreover, methane production, biogas production, and the $\mathrm{COD}$ removal rate rapidly dropped to their lowest values at $3{ }^{\circ} \mathrm{C}$, at which point the reactor was considered to be acidified. Recovery from this deteriorated condition occurred at $4{ }^{\circ} \mathrm{C}$; as indicated by a rapid increase in methane content, biogas production, the COD removal rate, 
and $\mathrm{pH}$, as well as the degradation of accumulated VFA. Following this VFA degradation, acetate and propionate concentrations gradually decreased to the concentrations that were measured at temperatures greater than $3{ }^{\circ} \mathrm{C}$, indicating the resumption of stable reactor operation. The presence of formic and butyrate was not detected at any point, we believe that it may have been below the lower limit of detection.

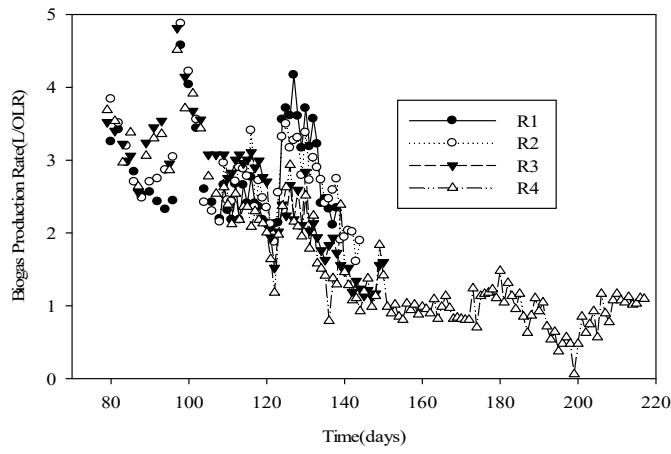

(A)

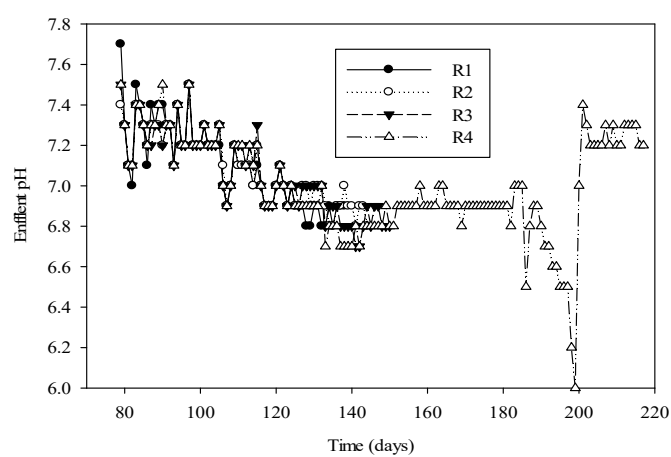

(C)

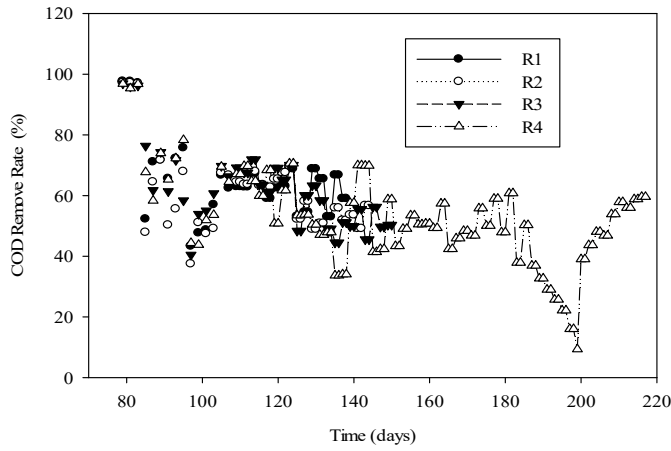

(B)

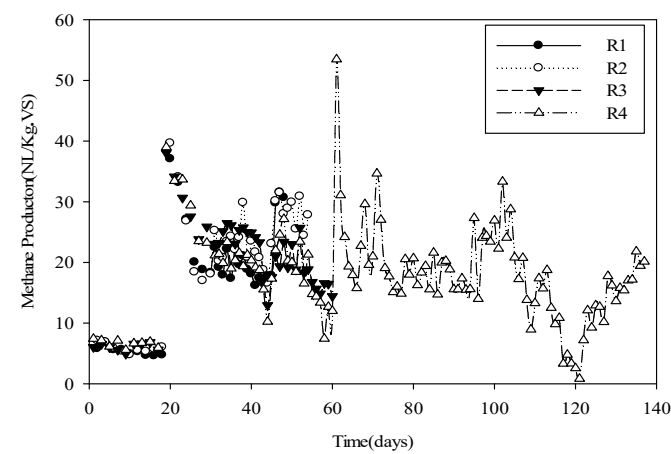

(D)

Figure 2. Changes in bioreactor performance over time during the operating period including the following parameters: (A) biogas production; (B) COD removal rate; (C) effluent $\mathrm{pH}$; (D) methane production.

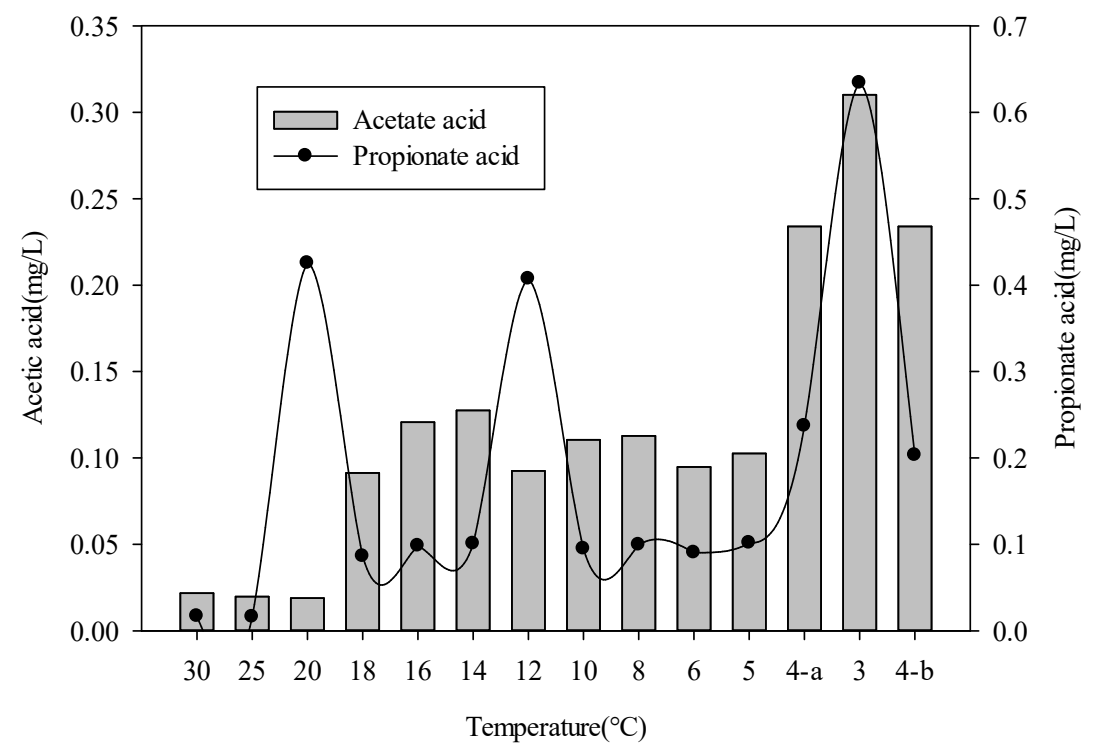

Figure 3. Temperature-dependent changes in effluent volatile fatty acids, including acetic acid and propionate acid. 4-a: Operating temperature of the reactor before the medium soured; 4-b: Recovery at $4{ }^{\circ} \mathrm{C}$ after the reactor medium soured. 


\subsection{Archaea DGGE Profiles}

In the four reactors, dynamic shifts in archaea were apparent between the temperatures of $18^{\circ} \mathrm{C}, 10^{\circ} \mathrm{C}, 8^{\circ} \mathrm{C}, 6^{\circ} \mathrm{C}, 4^{\circ} \mathrm{C}$, and $3^{\circ} \mathrm{C}$; PCR-DGGE showed 12 distinct bands (Figure 4A). The levels of archaeal diversity in the adherent and deposited sludge differed, with the greatest diversity found in the adherent archaea of the carbon-fiber carrier, particularly at $10{ }^{\circ} \mathrm{C}, 8{ }^{\circ} \mathrm{C}, 6^{\circ} \mathrm{C}$ and $4{ }^{\circ} \mathrm{C}$. The microbial diversity of the adhered and deposited sludge was enriched at $8{ }^{\circ} \mathrm{C}$ in comparison with the other temperatures. This relatively high level of diversity may explain the increased biogas production that was observed at $8{ }^{\circ} \mathrm{C}$ in comparison with the biogas measurements at other temperatures. We only detected three bands (band 5 , band 11 , and band 12 ) at $3{ }^{\circ} \mathrm{C}$, which suggests that microbial community activity decreased at this temperature, which is when the fixed-bed anaerobic reactor became acidified. Bands 5, 11, and 12 were observed in samples from the deposited sludge at different temperatures. Band 8 was observed in samples from adherent and deposited sludge. Bands 13 and 14 were detected at $8{ }^{\circ} \mathrm{C}$, whereas band 16 was detected at $8{ }^{\circ} \mathrm{C}, 6^{\circ} \mathrm{C}$, and $4{ }^{\circ} \mathrm{C}$, and band 17 was detected on the carbon-fiber carrier at only $6{ }^{\circ} \mathrm{C}$ and $4{ }^{\circ} \mathrm{C}$.

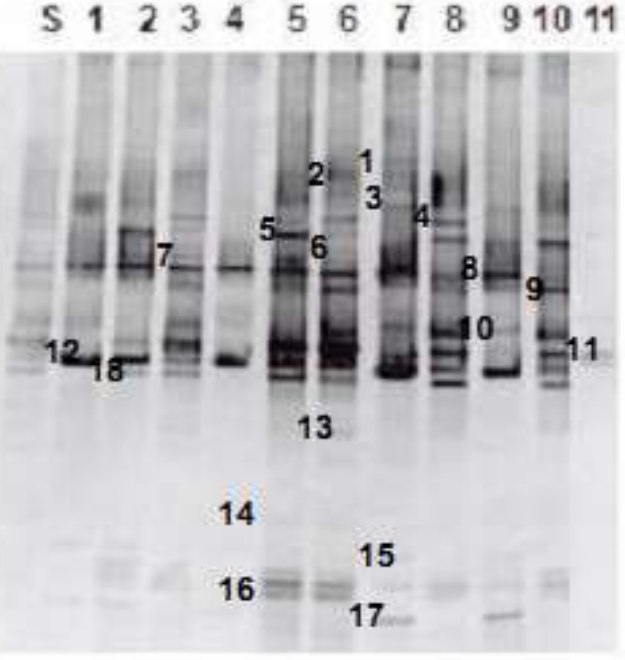

(A)

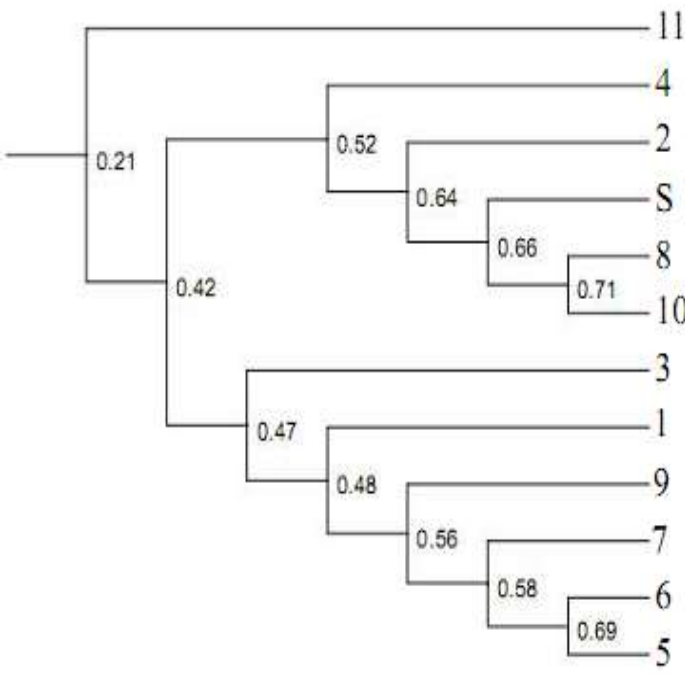

(B)

Figure 4. Denaturing gradient gel electrophoresis (DGGE) showing changes in the archaea population in the fixed-bed reactors. (A) Archaea bands; (B) Systematic trees from DGGE band analysis. S: seed sludge sample; 1, 3, 5, 7, 9: adherent sludge at $18{ }^{\circ} \mathrm{C}, 10{ }^{\circ} \mathrm{C}, 8{ }^{\circ} \mathrm{C}, 6{ }^{\circ} \mathrm{C}$, and $4{ }^{\circ} \mathrm{C} ; 2,4,6,8,10,11$ : deposition sludge at $18{ }^{\circ} \mathrm{C}, 10{ }^{\circ} \mathrm{C}, 8{ }^{\circ} \mathrm{C}, 6{ }^{\circ} \mathrm{C}, 4{ }^{\circ} \mathrm{C}$, and $3{ }^{\circ} \mathrm{C}$.

We also observed similarities among archaea communities, as indicated in the phylogenetic tree, with the archaea in the adherent sludge in one group and those in the deposited sludge in another (Figure 4B). The bands from the $3{ }^{\circ} \mathrm{C}$ sample (lane 11) were clearly distinct from those in any of the other lanes, with only a $21 \%$ similarity. The bands from the carrier sludge (collected from the carbon fibers) and deposited sludge at $8{ }^{\circ} \mathrm{C}$, in lanes 5 and 6, respectively, were clustered into one group with a $69 \%$ similarity, perhaps explaining the observation that biogas production at $8{ }^{\circ} \mathrm{C}$ exceeded that at $10^{\circ} \mathrm{C}, 6^{\circ} \mathrm{C}$, and $4{ }^{\circ} \mathrm{C}$. There was a $71 \%$ similarity between the bands from the deposited sludge at $6{ }^{\circ} \mathrm{C}$ (lane 8) and $4{ }^{\circ} \mathrm{C}$ (lane 10), indicating that the microbial communities in the deposited sludge at these temperatures were similar.

\subsection{Methanogenic Community Clone Library Analysis}

By gradually decreasing the operating temperature of the fixed-bed reactors, we studied the dynamics of methanogenic communities under psychrophilic conditions at $10-4{ }^{\circ} \mathrm{C}$ from days 122-182. A previous study indicated that the diversity of the methanogenic community remains stable over time [9]. Using complete 16S rRNA gene sequences, a gene clone library and a phylogenetic tree was created in order to further analyze the deposited, adherent, and 
seed sludge (Figure 5). Methanosaetaceae was the dominant methanogen in the eight OTUs that were identified in the seed sludge. We identified fourteen different OTUs in the carbonfiber carrier, of which $67.1 \%$ and $32.8 \%$ were methanomicrobiales and methanosarcinales, respectively. We identified fourteen different OTUs in the deposited sludge, of which $82.4 \%$ and $21.4 \%$ were methanosarcinales and methanomicrobiales, respectively.

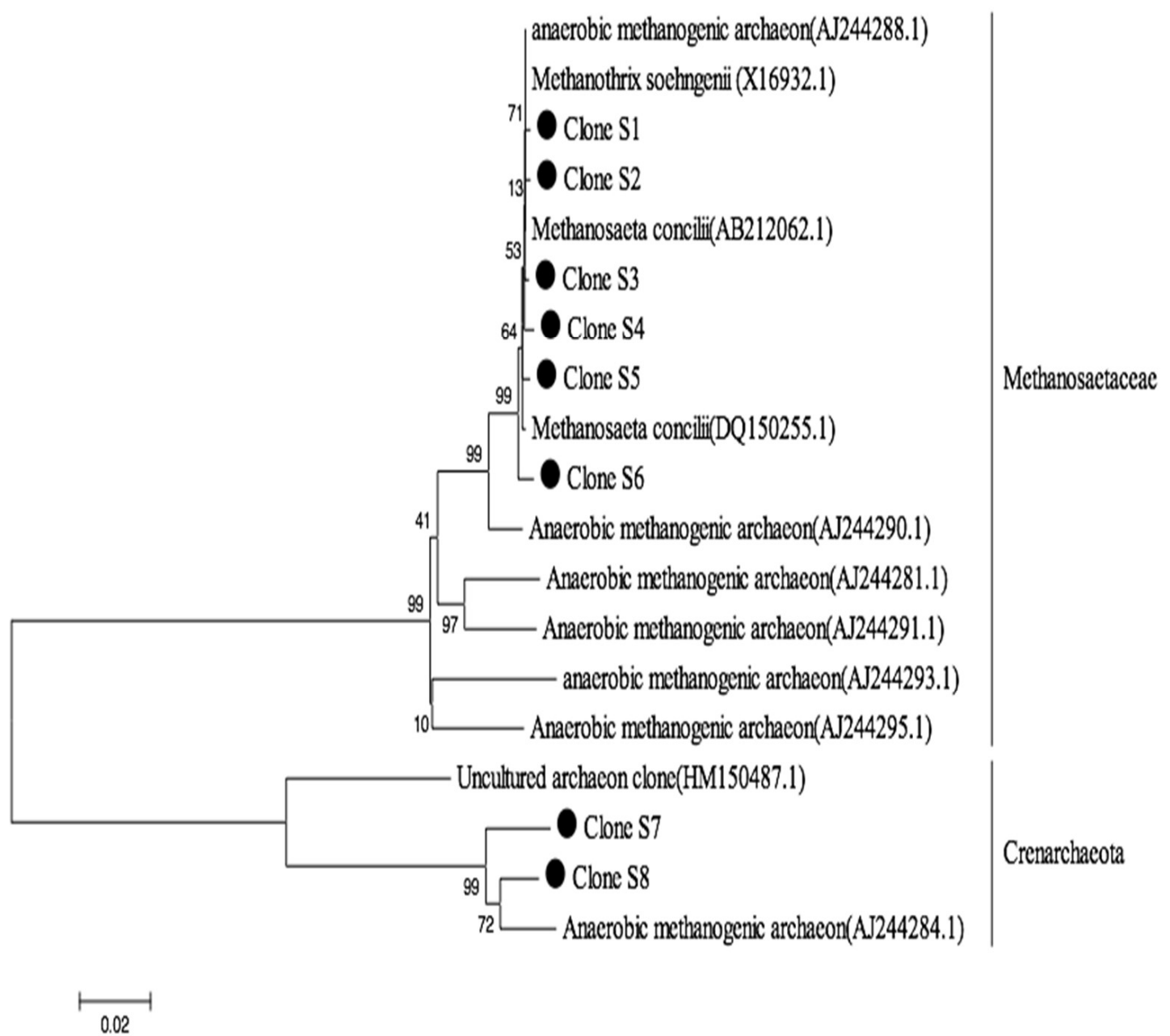

(S)

Figure 5. Cont. 


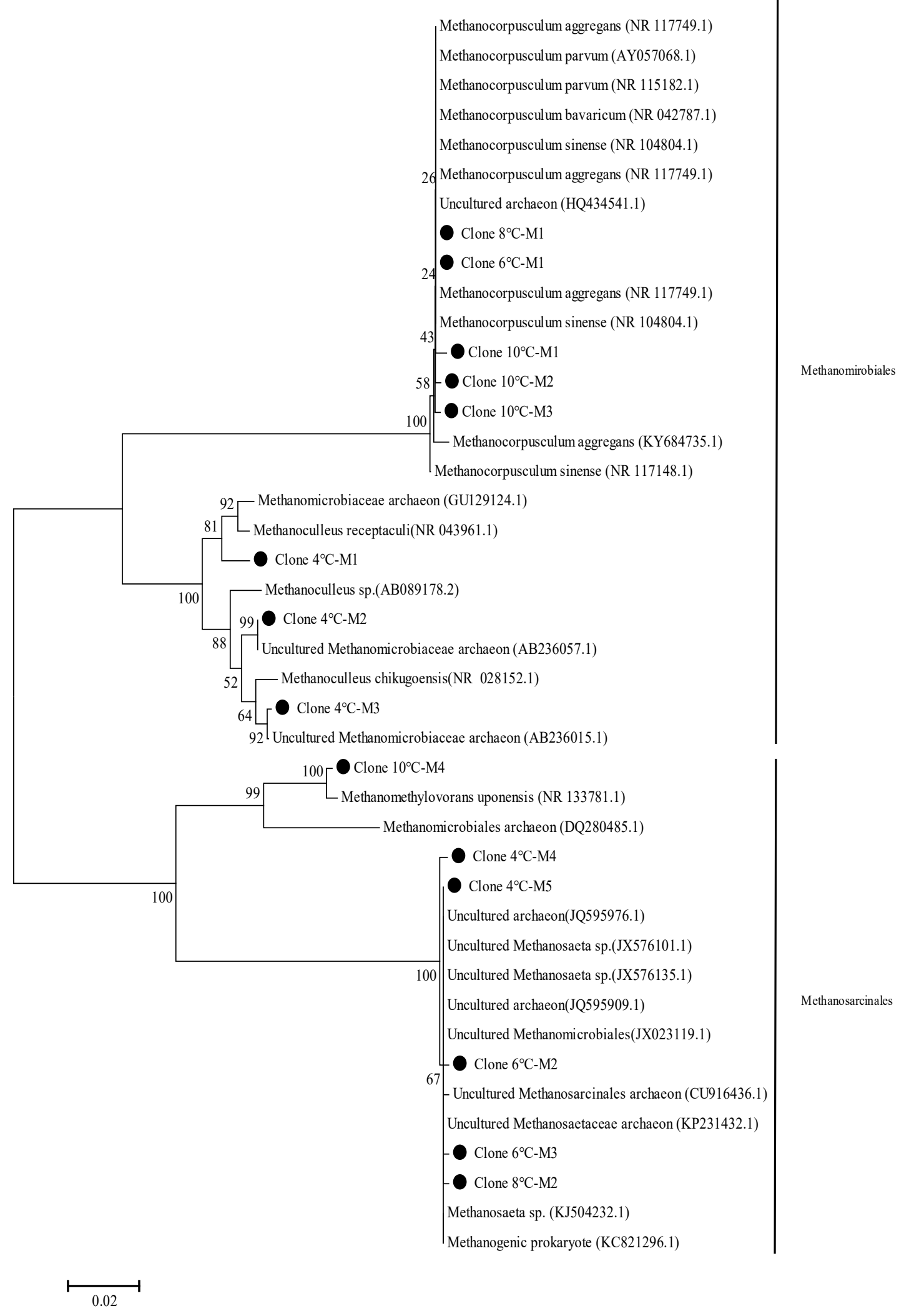

(M)

Figure 5. Cont. 


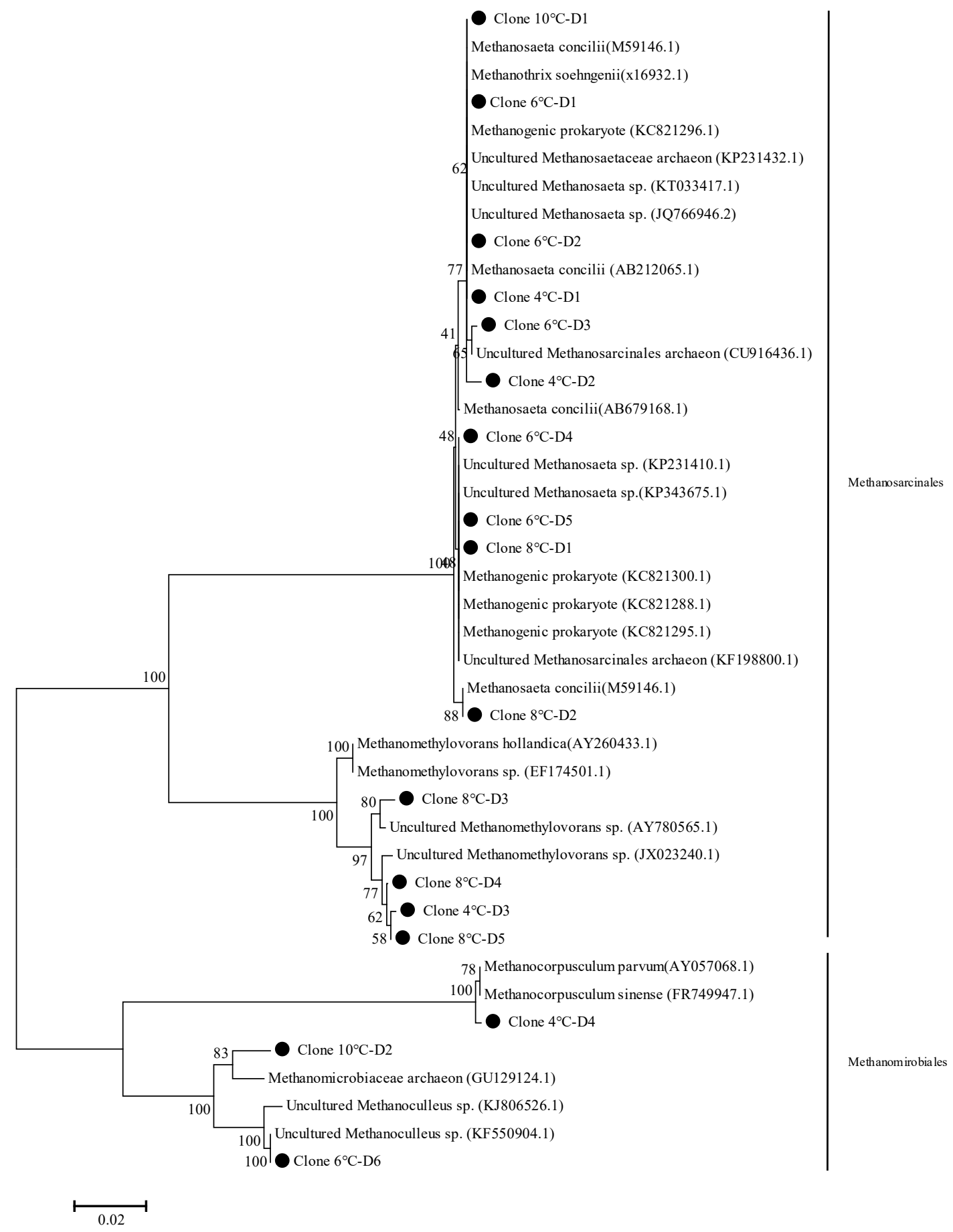

(D)

Figure 5. Phylogenetic tree showing the relationship among clones from seed sludge (S), adherent sludge (M), deposited sludge (D), and reference organisms. Solid circles $(\bullet)$ indicate clones from the sludge samples. Accession numbers are in parentheses for reference sequences from the GenBank database. The phylogenetic tree was constructed using the neighbor-joining method. Numbers shown at branch points are bootstrap values representing 1000 replications. The three bars signify $2 \%$ and $5 \%$ sequence divergence.

Following the stabilization of the fixed-bed reactors at low temperatures, several methanomicrobiale-related populations colonized the carbon-fiber carrier during the $10-4{ }^{\circ} \mathrm{C}$ temperature period, including clone $10{ }^{\circ} \mathrm{C}-\mathrm{M} 1$ (Methanocorpusculum aggregans, 
99\%), $10{ }^{\circ} \mathrm{C}-\mathrm{M} 2$ (Methanocorpusculum sinense, $98 \%$ ), $10{ }^{\circ} \mathrm{C}-\mathrm{M} 3$ (Methanocorpusculum parvum, 98\%), $4{ }^{\circ} \mathrm{C}-\mathrm{M} 1$ (Methanomicrobiaceae archaeon, 99\%), $4{ }^{\circ} \mathrm{C}-\mathrm{M} 2$ (Uncultured Methanomicrobiaceae, 98\%), $4{ }^{\circ} \mathrm{C}-\mathrm{M} 3$ (Methanoculleus chikugoensis, $98 \%$ ), and methanomicrobiales (OTUs, 67.1\%; fixed-bed reactor, dominant methanogens). The results showed that methanomicrobiales had a strong colony capacity under $10{ }^{\circ} \mathrm{C}$ and $4{ }^{\circ} \mathrm{C}$, and it was confirmed that the peak biogas production of the fixed-bed carbon-fiber carrier reactor occurred at $8{ }^{\circ} \mathrm{C}$, while the low-temperature threshold for stable operation was $4{ }^{\circ} \mathrm{C}$. Previously published studies reported that methanomicrobiales are key organisms of lowtemperature (psychrophilic) anaerobic granular-sludge systems, in which methane production is accomplished by hydrogenotrophic methanogenesis $[18,38,39]$. Hydrogenotrophic methanogenesis occurs in reactors with methanomicrobiales in proportions of 1-29\% [40]. Low temperatures impede the syntrophic degradation of VFAs, thereby decreasing the $\mathrm{H}_{2}$ threshold concentration. According to thermodynamic analysis, low temperatures reduce the efficiency of syntrophic propionate and butyrate degradation reactions [41]. At $4{ }^{\circ} \mathrm{C}$, hydrogenotrophic methanogenesis is a more important factor in comparison with its role at other temperatures [11]. Therefore, the hydrogenotrophic methanogenesis metabolic pathway dominated at low temperatures. We previously reported that the resistance to extreme changes in external environments in a carbon-fiber carrier containing a fixed-bed anaerobic reactor was mainly due to the following: (1) methanomicrobiales could easily attach to the carbon-fiber carrier; (2) hydrogenotrophic methanogenic activity was elevated; and (3) a stabile microbial system was achieved [18,30].

In the adhering carbon-fiber carrier sludge, methanosarcinale OTUs comprised $32.8 \%$ of the microbes when the fixed-bed reactor was operated at $10-4{ }^{\circ} \mathrm{C}$. An abundance of methanosaetaceae was found in the adhering carbon-fiber carrier sludge, which contrasts with reports suggesting that the methanosaeta species are important participants in anaerobic granulation [38].

Moreover, in the fixed-bed reactor, methanosarcinales were also most abundant at psychrophilic conditions in the sludge adhering to the carbon-fiber biofilm. Fourteen different clones were identified at operating temperatures of $10-4{ }^{\circ} \mathrm{C}$.

\subsection{Quantitative Analysis of the Methanogenic Community}

Quantitative alterations in the methanogenic community composition of the deposited sludge and the carbon-fiber carrier at $10^{\circ} \mathrm{C}, 8{ }^{\circ} \mathrm{C}, 6^{\circ} \mathrm{C}, 4^{\circ} \mathrm{C}$, and $3{ }^{\circ} \mathrm{C}$ were determined using real-time PCR (Figure 6). The predominant species in the seed sludge was methanosaetaceae, which accounted for $85.28 \%$ of the methanogens (sum of the concentrations of all quantified 16S rRNA genes). This finding is consistent with the results of our clonal analysis, as well as published reports showing abundant methanosaetaceae-related species in stable granular anaerobic digesters $[9,18]$.

At $10{ }^{\circ} \mathrm{C}, 8{ }^{\circ} \mathrm{C}, 6^{\circ} \mathrm{C}$ and $4{ }^{\circ} \mathrm{C}$, the $16 \mathrm{~S}$ rRNA gene concentration in the carbon-fiber carrier sludge was $65.82 \%, 20.61 \%, 72.13 \%$, and $79.60 \%$ greater, respectively, than in the deposition sludge. The $16 \mathrm{~S}$ rRNA gene concentration in the deposition sludge at $8{ }^{\circ} \mathrm{C}$ was greater than that observed at $10{ }^{\circ} \mathrm{C}, 6^{\circ} \mathrm{C}$, and $4{ }^{\circ} \mathrm{C}$, and was not significantly different from that of the carbon-fiber carrier sludge. These results were subsequently confirmed by our analysis of the DGGE profile and provide an explanation for why the level of biogas production was higher at $8{ }^{\circ} \mathrm{C}$ relative to that observed at $10^{\circ} \mathrm{C}, 6{ }^{\circ} \mathrm{C}$, and $4{ }^{\circ} \mathrm{C}$. 


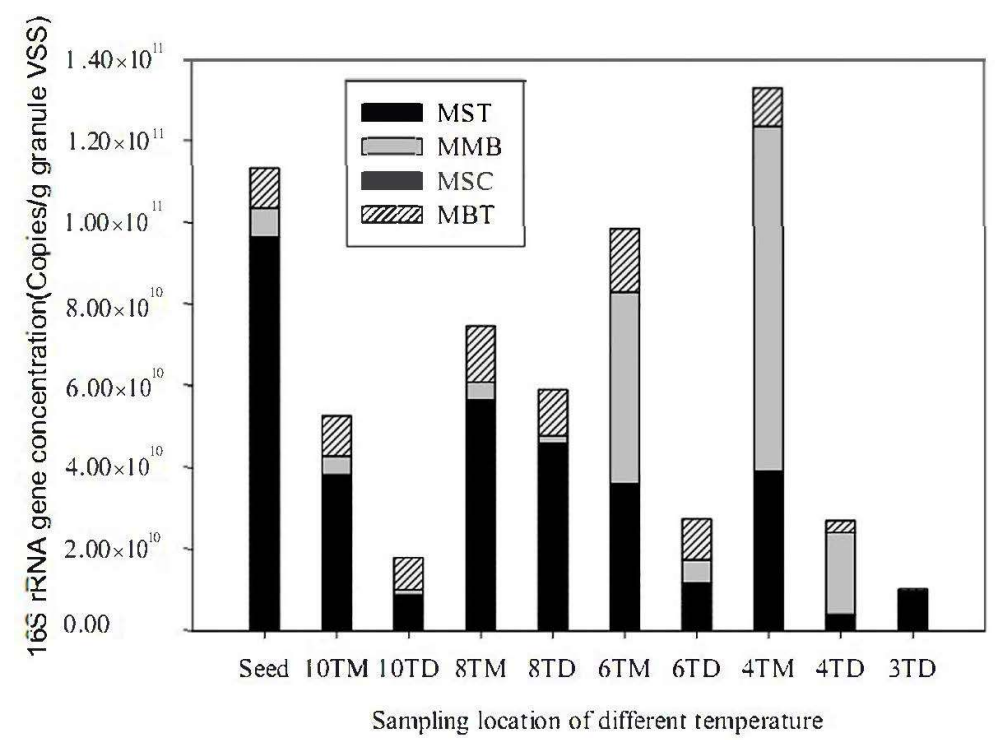

Figure 6. Quantitative changes in $16 \mathrm{~S}$ rRNA gene concentrations for different methanogenic archaea in adherent and deposited sludge. Granular biomass samples were collected from seed inoculum (S), adherent sludge (TM), and deposited sludge (TD) of the four reactors.

The methanomicrobiale 16S rRNA gene concentration increased in comparison with that of the other measured $16 \mathrm{~S}$ rRNA genes as the temperature gradually decreased. In the carbon-fiber carrier, methanomicrobiale $16 \mathrm{~S}$ rRNA gene concentrations were greater than the gene concentrations that were found in the deposited sludge at $10{ }^{\circ} \mathrm{C}, 8^{\circ} \mathrm{C}$, $6{ }^{\circ} \mathrm{C}$ and $4{ }^{\circ} \mathrm{C}$. The methanomicrobiale $16 \mathrm{~S}$ rRNA gene concentration at $6{ }^{\circ} \mathrm{C}$ and $4{ }^{\circ} \mathrm{C}$ in the carbon-fiber carrier was $87.95 \%$ and $76.16 \%$ greater, respectively, than that of the deposited sludge. The methanomicrobiale 16S rRNA gene concentration in the deposited sludge also gradually increased and was especially high at $4{ }^{\circ} \mathrm{C}$. In the methanogenic population, $74.1 \%$ of the $16 \mathrm{~S}$ rRNA gene concentration came from the deposited sludge, and the results showed that the methanomicrobiales gradually became dominant in the fixed-bed anaerobic digestion reactor at low temperatures.

These results are in agreement with reports that methanomicrobiales preferentially adhere to a carbon-fiber carrier in fixed-bed reactors, as well as studies of the methanogen dominance under psychrophilic conditions $[12,18]$. These findings are also in agreement with our analysis of the clonal library, in which methanomicrobiales were the dominant methanogen.

When the operation temperature was reduced to $3{ }^{\circ} \mathrm{C}$, the fixed-bed reactors soured, the adherent sludge dropped off, and microbial activity decreased. Therefore, we also determined the 16S rRNA gene concentration of the deposited sludge; methanosaetaceae accounted for $95.43 \%$ of the measured methanogenic population, and methanosaetaceae was the dominant methanogen species. The diversity and biomass of methanosaetaceae were enriched at low temperatures, and the methanosaetaceae $16 \mathrm{~S}$ rRNA gene concentration accounted for $29.54 \%$ of the detected methanogenic population at $4{ }^{\circ} \mathrm{C}$. These results suggest that methanosaetaceae are essential for the formation of anaerobic sludge granules and contribute to the well-settling granular morphotype of adherent sludge under psychrophilic conditions. Several studies have indicated that stable, well-settling microbial aggregates are crucial for the stable operation of such reactors, although the precise mechanism for the formation of sludge granules is not completely clear [38].

We observed the order methanobacteriales in the seed sludge of all reactors, and its population did not vary markedly, except for the samples that were collected at $3{ }^{\circ} \mathrm{C}$ and in the deposited sludge that was collected at $4{ }^{\circ} \mathrm{C}$, and was mostly maintained at greater than 109 copies/g of VSS granules in all reactors. Species in the same genus grow at temperatures as low as $4^{\circ} \mathrm{C}$ [7], providing further evidence for the adaptation 
to psychrophilic conditions. The presence of methanococcales was not indicated during the experiment.

\section{Advantages of Fixed-Bed Reactor Operation at Low Temperature}

Biogas production, $\mathrm{pH}, \mathrm{COD}$ removal rate, and VFA abundance returned to their initial levels when the temperature of the fixed-bed anaerobic reactor was increased from $3{ }^{\circ} \mathrm{C}$ to $4{ }^{\circ} \mathrm{C}$ for 18 days (Figures 2 and 3). Previous reports indicated that some types of anaerobic reactors can operate at $4{ }^{\circ} \mathrm{C}[7,9,11,14,36]$, but the temperature threshold for operation under low-temperature conditions remains unknown; in particular, little is known regarding the performance of fixed-bed reactors that are packed with active carbon-fiber and subjected to a psychrophilic environment.

For a fixed-bed reactor at a temperature of $8^{\circ} \mathrm{C}$, the COD concentration is $5000 \mathrm{mg} / \mathrm{L}$, the biogas yield is $3.2 \mathrm{~L}$, the methane content is $77.8 \%$, and $1 \mathrm{~g}$ of COD produces $497 \mathrm{~mL}$ of methane, which is far higher than its theoretical production of $350 \mathrm{~mL}$ [42]. In addition, a fixed-bed reactor at a temperature of $4{ }^{\circ} \mathrm{C}$ has a COD concentration of $2000 \mathrm{mg} / \mathrm{L}$, a biogas yield of $1.1 \mathrm{~L}$, a methane content of about $60 \%$, and $1 \mathrm{~g}$ of COD produces $330 \mathrm{~mL}$ of methane, which is slightly lower than the theoretical value. According to the equation of heating fluid consumption, $\mathrm{QL}=\rho \mathrm{VC} \Delta \mathrm{t}$ of the heated material, which is calculated by the amount of heating material; the amount of heat is the density of the liquid, which at $4{ }^{\circ} \mathrm{C}$ is $1003.3 \mathrm{~kg} / \mathrm{m}^{3}$ and at $35^{\circ} \mathrm{C}$ is $1330 \mathrm{~kg} / \mathrm{m}^{3} ; \mathrm{V}=4 \times 10^{-3} \mathrm{~m}^{3} / \mathrm{d} ; \mathrm{C}$ is the heat ratio, with a value of $4.2 \mathrm{~kJ} /\left(\mathrm{kg}^{\circ} \mathrm{C}\right) ; \Delta \mathrm{t}$ is an elevated temperature [43]. This equation takes into account only the energy consumed by heating, which was $4.7 \mathrm{kw}$ more than that at $4{ }^{\circ} \mathrm{C}$. Therefore, from the point of view of energy consumption and energy production, anaerobic fermentation wastewater is suitable.

Our previous reports confirmed that carbon-fiber carrier fixed-bed reactors were resistant to organic loading-rate shock, and the reactor efficiency was highest when OLR was $4.33 \mathrm{~kg} \mathrm{COD} / \mathrm{m}^{3} \cdot \mathrm{d}$ at $4{ }^{\circ} \mathrm{C}$ [14]. To our knowledge, most studies of anaerobic bioreactors have assessed their stable long-term operation, and they have mainly been carried out between $15-4{ }^{\circ} \mathrm{C}$. Expanded granular-sludge-bed anaerobic filters (EGSB-AF), expanded granular-sludge beds (EGSB), batches, and UASBs (upflow anaerobic sludge-bed reactors) have been shown to be suitable for anaerobic treatment of domestic wastewater at a wide range of temperatures and treatment periods $\left(4-15^{\circ} \mathrm{C}\right.$ for 1234 days; $4-8{ }^{\circ} \mathrm{C}$ for 200 days; 4,8 and $15^{\circ} \mathrm{C}$ for 400 days; $4-10^{\circ} \mathrm{C}$ for 250 days). However, carbon-fiber carrier fixed-bed reactors have been shown to be suitable for anaerobic treatment of real molasses wastewater at $5-18{ }^{\circ} \mathrm{C}$ and $4-10{ }^{\circ} \mathrm{C}$ for 78 days and 60 days. The carbon-fiber-carrier fixed-bed-reactor configuration enables a high rate of conversion at a low temperature and a strong resistance to shock. Methanomicrobiale colonization played a crucial role in the carbon-fiber carriers, while improving sludge activity and shock resistance. Low temperatures have been reported to severely inhibit the activity of microorganisms and sludge, and this phenomenon could be a result of adaptation by microorganisms $[9,37,38]$. The biggest challenges in anaerobic wastewater treatment are the short hydraulic-retention times and short sludge-retention times that are associated with low temperatures. However, at low temperatures, the viscosity of liquids is also increased, and biofilm attachment on the carrier lengthens the average residence time, thus providing advantageous acclimation conditions for slow-growing microbes. In addition, sludge expansion on the biomembrane and sludge wash-out are reduced, which can enhance the shock resistance and stability of the reactor when it is subjected to adverse environmental conditions [14,18,21,30]. Biofilm treatment systems have a higher resistance to low temperatures compared to other systems, and they are able to maintain and protect methanogens that cannot colonize, but which reproduce rapidly. Lowering the operation temperature of these systems might lead to an increased net biomass yield of the methanogenic population $[7,18,44]$. The operation of high-efficiency wastewater treatment reactors at psychrophilic temperatures is of major importance as a technique for minimizing energy consumption, reducing capital and operational costs, and obtaining a sufficient bioenergy harvest $[7,13]$. Molasses wastewater that 
is discharged from the sugar industry contains many compounds at high concentrations, which make such wastewater difficult to treat compared with synthetic wastewater, while also inhibiting methanogenesis $[14,19]$.

Based on the results presented here, we believe that, in comparison with other nonbiofilm system reactors, carbon-fiber carrier fixed-bed reactors have the advantage of impact resistance, quick start-up, and high-efficiency operation.

\section{Conclusions}

We investigated the practicality of biogas production in a fixed-bed anaerobic reactor at a low temperature with a gradual decrease in temperature for 217 days. Reactor performance was stable at $4{ }^{\circ} \mathrm{C}$, indicating that this temperature was the low temperature threshold for operation, and the biogas production, methane production and COD removal rate were $1.47 \mathrm{~L} / \mathrm{kg} \mathrm{COD} / \mathrm{m}^{3} \cdot \mathrm{d}, 71.4 \%$, and $15.69 \mathrm{NL} / \mathrm{Kg} \cdot \mathrm{VS}$, respectively. The optimal temperatures that achieved the most biogas production in the four reactors were $18{ }^{\circ} \mathrm{C}$ and $8{ }^{\circ} \mathrm{C}$. Methanomicrobiales were the dominant methanogen at a low temperature. The carbon-fiber carrier fixed-bed reactors have the advantage of low-temperature impact resistance, quick start-up and high-efficiency operation.

Author Contributions: H.Z.: Conceptualization, Data curation, Formal analysis, Investigation, Methodology, Writing — original draft, Funding acquisition. H.L.: Investigation, Data curation, Methodology, Formal analysis, Writing—original draft, Visualization, Supervision. Y.S.: Formal analysis, Investigation, Methodology, Visualization. L.Z.: Formal analysis, Investigation, Methodology, Visualization. U.F.: Investigation, Validation, Writing — review \& editing. R.P.: Conceptualization, Methodology, Project administration, Resources. W.W.: Validation, Funding acquisition, Writing-review \& editing. Z.C.: Conceptualization, Supervision, Funding acquisition, Project administration, Writing-review \& editing. All authors have read and agreed to the published version of the manuscript.

Funding: This work was supported by the National Science Foundation of China (no. 51741809), the Special Fund for Agro-scientific Research in the Public Interest (no. 201503137), the National Key Technology Research and Development Program of China (no. 2015BAD21B04), the Key Research and Development Project of Science and Technology Department of Jilin Province (no. 20200402040NC, 20200103028SF) and the Jilin Provincial Education Department Project (no. JJKH20191130KJ).

Institutional Review Board Statement: Not applicable.

Informed Consent Statement: Not applicable.

Data Availability Statement: Data is being uploaded to NCBI and will be provided during the review period.

Conflicts of Interest: The authors declare no conflict of interest.

\section{References}

1. Angelidaki, I.; Treu, L.; Tsapekos, P.; Luo, G.; Campanaro, S.; Wenzel, H.; Kougias, P.G. Biogas upgrading and utilization: Current status and perspectives. Biotechnol. Adv. 2018, 36, 452-466. [CrossRef]

2. Westerholm, M.; Isaksson, S.; Karlsson Lindsjö, O.; Schnürer, A. Microbial community adaptability to altered temperature conditions determines the potential for process optimisation in biogas production. Appl. Energy 2018, 226, 838-848. [CrossRef]

3. Wu, P.H.; Ng, K.K.; Hong, P.K.A.; Yang, P.Y.; Lin, C.F. Treatment of low-strength wastewater at mesophilic and psychrophilic conditions using immobilized anaerobic biomass. Chem. Eng. J. 2017, 311, 46-54. [CrossRef]

4. Lin, R.; Cheng, J.; Ding, L.; Murphy, J.D. Improved efficiency of anaerobic digestion through direct interspecies electron transfer at mesophilic and thermophilic temperature ranges. Chem. Eng. J. 2018, 350, 681-691. [CrossRef]

5. Wu, L.-J.; Higashimori, A.; Qin, Y.; Hojo, T.; Kubota, K.; Li, Y.-Y. Comparison of hyper-thermophilic-mesophilic two-stage with single-stage mesophilic anaerobic digestion of waste activated sludge: Process performance and microbial community analysis. Chem. Eng. J. 2016, 290, 290-301. [CrossRef]

6. Wang, L.; Zhang, J.; Feng, L.; Zhang, L. Effectiveness research of membrane bioreactor process treating low-temperature wastewater. Chin. J. Environ. Eng. 2011, 5, 1263-1267.

7. Smith, A.L.; Skerlos, S.J.; Raskin, L. Anaerobic membrane bioreactor treatment of domestic wastewater at psychrophilic temperatures ranging from $15^{\circ} \mathrm{C}$ to $3{ }^{\circ} \mathrm{C}$. Environ. Sci. Water Res. Technol. 2015, 1, 56-64. [CrossRef]

8. Lettinga, G.; Rebac, S.; Zeeman, G. Challenge of psychrophilic anaerobic wastewater treatment. Trends Biotechnol. 2001, 19, 363-370. [CrossRef] 
9. Petropoulos, E.; Dolfing, J.; Davenport, R.J.; Bowen, E.J.; Curtis, T.P. Developing cold-adapted biomass for the anaerobic treatment of domestic wastewater at low temperatures $\left(4,8\right.$ and $\left.15^{\circ} \mathrm{C}\right)$ with inocula from cold environments. Water Res. 2017, 112, 100-109. [CrossRef]

10. Deng, L.; Yang, H.; Liu, G.; Zheng, D.; Chen, Z.; Liu, Y.; Pu, X.; Song, L.; Wang, Z.; Lei, Y. Kinetics of temperature effects and its significance to the heating strategy for anaerobic digestion of swine wastewater. Appl. Energy 2014, 134, 349-355. [CrossRef]

11. McKeown, R.M.; Scully, C.; Mahony, T.; Collins, G.; O’Flaherty, V. Long-term (1243 days), low-temperature (4-15 $\left.{ }^{\circ} \mathrm{C}\right)$, anaerobic biotreatment of acidified wastewaters: Bioprocess performance and physiological characteristics. Water Res. 2009, 43, 1611-1620. [CrossRef]

12. Siggins, A.; Enright, A.M.; O’Flaherty, V. Low-temperature (7 degrees C) anaerobic treatment of a trichloroethylene-contaminated wastewater: Microbial community development. Water Res. 2011, 45, 4035-4046. [CrossRef]

13. Smith, K.; Liu, S.; Liu, Y.; Guo, S. Can China reduce energy for water? A review of energy for urban water supply and wastewater treatment and suggestions for change. Renew. Sustain. Energy Rev. 2018, 91, 41-58. [CrossRef]

14. Zhao, H.; Yan, F.; Li, X.; Piao, R.; Wang, W.; Cui, Z. Impact of Organic Loading Rate on Performance and Methanogenic Microbial Communities of a Fixed-Bed Anaerobic Reactor at $4{ }^{\circ} \mathrm{C}$. Water 2020, 12, 2586. [CrossRef]

15. Connaughton, S.; Collins, G.; O'Flaherty, V. Development of microbial community structure and actvity in a high-rate anaerobic bioreactor at $18^{\circ} \mathrm{C}$. Water Res. 2006, 40, 1009-1017. [CrossRef]

16. Raheem, A.; Sikarwar, V.S.; He, J.; Dastyar, W.; Dionysiou, D.D.; Wang, W.; Zhao, M. Opportunities and challenges in sustainable treatment and resource reuse of sewage sludge: A review. Chem. Eng. J. 2018, 337, 616-641. [CrossRef]

17. Yurtsever, A.; Calimlioglu, B.; Sahinkaya, E. Impact of SRT on the efficiency and microbial community of sequential anaerobic and aerobic membrane bioreactors for the treatment of textile industry wastewater. Chem. Eng. J. 2017, 314, 378-387. [CrossRef]

18. Zhang, D.; Zhu, W.; Tang, C.; Suo, Y.; Gao, L.; Yuan, X.; Wang, X.; Cui, Z. Bioreactor performance and methanogenic population dynamics in a low-temperature $\left(5-18^{\circ} \mathrm{C}\right)$ anaerobic fixed-bed reactor. Bioresour. Technol. 2012, 104, 136-143. [CrossRef]

19. Kuroda, K.C.; Nakahara, T.; Hatamoto, N.; Wakabayashi, M.; Kawai, T.; Araki, T.; Syutsubo, N.; Yamaguchi, K.T. High organic loading treatment for industrial molasses wastewater and microbial community shifts corresponding to system development. Bioresour. Technol. 2015, 196, 225-234. [CrossRef]

20. Li, L.; Yuan, Z.; Sun, Y.; Kong, X.; Dong, P.; Zhang, J. A reused method for molasses-processed wastewater: Effect on silage quality and anaerobic digestion performance of Pennisetum purpereum. Bioresour. Technol. 2017, 241, 1003-1011. [CrossRef]

21. Meng, X.Y.; Yuan, X.; Ren, J.; Wang, X.; Zhu, W.; Cui, Z. Methane production and characteristics of the microbial community in a two-stage fixed-bed anaerobic reactor using molasses. Bioresour. Technol. 2017, 241, 1050-1059. [CrossRef] [PubMed]

22. Zhang, D.; Li, J.; Guo, P.; Li, P.; Suo, Y.; Wang, X.; Cui, Z. Dynamic transition of microbial communities in response to acidification in fixed-bed anaerobic baffled reactors (FABR) of two different flow directions. Bioresour. Technol. 2011, 102, 4703-4711. [CrossRef] [PubMed]

23. Lew, B.; Tarre, S.; Beliavski, M.; Green, M. Anaerobic degradation pathway and kinetics of domestic wastewater at low temperatures. Bioresour. Technol. 2009, 100, 6155-6162. [CrossRef]

24. Sasaki, K.; Morita, M.; Hirano, S.; Ohmura, N.; Igarashi, Y. Effect of adding carbon fiber textiles to methanogenic bioreactors used to treat an artificial garbage slurry. J. Biosci. Bioeng. 2009, 108, 130-135. [CrossRef] [PubMed]

25. Salvador, M.; Haruta, S.; Hazaka, M.; Shimada, R.; Yoshida, C.; Hiura, K.; Ishii, M.; Igarashi, Y. Denaturing gradient gel electrophoresis analyses of microbial community from field-scale composter. J. Biosci. Bioeng. 2001, 91, 159-165. [CrossRef]

26. Lueders, T.; Friedrich, M.W. Effects of Amendment with Ferrihydrite and Gypsum on the Structure and Activity of Methanogenic Populations in Rice Field Soil. Appl. Environ. Microbiol. 2002, 68, 2484-2494. [CrossRef]

27. Gao, L.; Yang, H.; Wang, X.; Huang, Z.; Ishii, M.; Igarashi, Y.; Cui, Z. Rice straw fermentation using lactic acid bacteria. Bioresour. Technol. 2008, 99, 2742-2748. [CrossRef]

28. Tamura, K.; Dudley, J.; Nei, M.; Kumar, S. MEGA4: Molecular evolutionary genetics analysis (MEGA) software version 4.0. Mol. Biol. Evol. 2007, 24, 1596-1599. [CrossRef]

29. Yu, Y.; Lee, C.; Kim, J.; Hwang, S. Group-specific primer and probe sets to detect methanogenic communities using quantitative real-time polymerase chain reaction. Biotechnol. Bioeng. 2005, 89, 670-679. [CrossRef]

30. Zhao, H.; Li, J.; Li, J.; Yuan, X.; Piao, R.; Zhu, W.; Li, H.; Wang, X.; Cui, Z. Organic loading rate shock impact on operation and microbial communities in different anaerobic fixed-bed reactors. Bioresour. Technol. 2013, 140, 211-219. [CrossRef]

31. Bandara, W.M.K.R.T.W.; Kindaichi, T.; Satoh, H.; Sasakawa, M.; Nakahara, Y.; Takahashi, M.; Okabe, S. Anaerobic treatment of municipal wastewater at ambient temperature: Analysis of archaeal community structure and recovery of dissolved methane. Water Res. 2012, 46, 5756-5764. [CrossRef]

32. Collins, G.; Foy, C.; McHugh, S.; Mahony, T.; O’Flaherty, V. Anaerobic biological treatment of phenolic wastewater at $15-18{ }^{\circ} \mathrm{C}$. Water Res. 2005, 39, 1614-1620. [CrossRef]

33. Kashyap, D.R.; Dadhich, K.S.; Sharma, S.K. Biomethanation under psychrophilic conditions: A review. Bioresour. Technol. 2003, 87, 147-153. [CrossRef]

34. Dhaked, R.K.; Singh, P.; Singh, L. Biomethanation under psychrophilic conditions. Waste Manag. 2010, 30, 2490-2496. [CrossRef]

35. O'Reilly, J.; Lee, C.; Collins, G.; Chinalia, F.; Mahony, T.; O'Flaherty, V. Quantitative and qualitative analysis of methanogenic communities in mesophilically and psychrophilically cultivated anaerobic granular biofilims. Water Res. 2009, 43, 3365-3374. [CrossRef] [PubMed] 
36. Kalyuzhnyl, S.V.; Gladchenko, M.A.; Skylar, V.I.; Kizimenko, Y.S.; Shcherbakov, S.S. One- and Two-Stage Upflow Anaerobic Sludge-Bed Reactor Pretreatment of Winery Wastewater at 4-10 ${ }^{\circ} \mathrm{C}$. Appl. Biochem. Biotechnol. 2001, 90, 107-124. [CrossRef]

37. Lettinga, G.; Rebic, S.; Parshina, S.; Nozhevnikoa, A.; Vanlier, J.; Stams, A. High-Rate Anaerobic Treatment of Wastewater at Low Temperatures. Appl. Environ. Microbiol. 1999, 65, 1696-1702. [CrossRef]

38. McKeown, R.M.; Hughes, D.; Collins, G.; Mahony, T.; O'Flaherty, V. Low-temperature anaerobic digestion for wastewater treatment. Curr. Opin. Biotechnol. 2012, 23, 444-451. [CrossRef] [PubMed]

39. Parshina, S.N.; Ermakova, A.V.; Bomberg, M.; Detkova, E.N. Methanospirillum stamsii sp. nov., a psychrotolerant, hydrogenotrophic, methanogenic archaeon isolated from an anaerobic expanded granular sludge bed bioreactor operated at low temperature. Int. J. Syst. Evol. 2014, 64, 180-186. [CrossRef]

40. Sekiguchi, Y.; Kamagata, Y. Microbial community structure and functions in methane fermentation technology for wastewater treatment. Strict and facultative anaerobes: Medical and environmental aspects. BioScience 2004, 361-384.

41. McKeown, R.M.; Scully, C.; Enright, A.M.; Chinalia, F.A.; Lee, C.; Mahony, T.; Collins, G.; O’Flaherty, V. Psychrophilic methanogenic community development during long-term cultivation of anaerobic granular biofilms. ISME J. 2009, 3, 1231-1242. [CrossRef] [PubMed]

42. Yoshinaga, M.Y.; Holler, T.; Goldhammer, T.; Wegener, G.; Pohlman, J.W.; Brunner, B.; Kuypers, M.; Hinrichs, K.; Elvert, M. Carbon isotope equilibration during sulphate-limited anaerobic oxidation of methane. Nat. Geosci. 2014, 7, 190-194. [CrossRef]

43. Liu, Y.F.; Chen, Y.W.; Li, T.; Wang, D.G.; Wang, D.K. Investigation on the heat loss characteristic of underground household biogas digester using dynamic simulations and experiments. Biosyst. Eng. 2017, 163, 116-133. [CrossRef]

44. Smith, A.L.; Skerlos, S.J.; Raskin, L. Psychrophilic anaerobic membrane bioreactor treatment of domestic wastewater. Water Res. 2013, 47, 1655-1665. [CrossRef] [PubMed] 